\title{
A NOTE ON THIS EDITION
}

Although often reprinted separately, Mark Twain's letters from Hawaii were never collected in book form until 1937, when the Grabhorn Press in San Francisco published, with an introduction and conclusion by G. Ezra Dane, a limited edition of 550 copies, entitled Letters from the Sandwich Islands and illustrated by Dorothy Grover. The following year a photo-offset reprint was issued by the Stanford University Press. The Dane volume omitted part of Letter 3 on Hawaiian trade and all of letters 10 (whaling), 15 (the Hornet disaster), and 23 (the sugar industry). These four letters were published in 1939 by Thomas Nickerson of Honolulu, with an introduction by John W. Vandercook; the volume, entitled Letters from Honolulu, was limited to one thousand copies and was printed by the Lakeside Press of Chicago. The first complete reprinting appeared as Appendix C of Mark Twain and Hawaii (1947), the excellent study by the late Walter Francis Frear, wellknown judge and third governor of the Territory of $\mathrm{Ha}-$ waii. Frear's book was also published by the Lakeside Press and limited to one thousand autographed copies. The first complete general edition, edited and with an introduction by A. Grove Day, was published in 1966 by AppletonCentury, New York. It is hoped that this reprinting of that edition, with a revised introduction, will win new readers for these charming letters by one of America's greatest writers. 
